\title{
IDENTIFIKASI RESOURCES CONSTRAINT PADA KINERJA PELAYANAN DENGAN PENDEKATAN THEORY OF CONSTRAINT DI INSTALASI RAWAT INAP RSU HAJI SURABAYA
}

\section{IDENTIFYING THE CONSTRAINT RESOURCES ON SERVICE PERFORMANCE WITH THE THEORY OF CONSTRAINT APPROACH ON INPATIENT INSTALLATION OF SURABAYA HAJJ HOSPITAL}

\author{
Vida Indira Puspita ${ }^{1}$, Setya Haksama ${ }^{1}$ \\ ${ }^{1}$ Departemen Administrasi Kebijakan dan Kesehatan \\ Fakultas Kesehatan Masyarakat Universitas Airlangga, Surabaya, Indonesia \\ Alamat Korespondensi: Vida Indria Puspita \\ Email: vidaindira@rocketmail.com
}

\begin{abstract}
The trend of Gross Death Rate (GDR) Surabaya Hajj Hospital had tended to increase from 2012 to 2015. However, it eventually decreased in 2016. This research aims to analyze the constraints in the service performance at the inpatient unit of Surabaya Hajj Hospital. The research utilized the theory of constraint to minimize the constraints and to prevent the trend of increased GDR over the years. The research employed observational descriptive and cross-sectional design. The primary data were directly collected from the nurses as respondents through questionnaires. The results of the research indicated that the resource constraints were the workload, lack of facilities, lack of medical and non-medical equipment, and lack of nurse workforce. In conclusion, with all the foregoing constraints, such as the workload, lack of facilities, medical, and non-medical equipment, and lack of nurse's workforce, do not directly affect the service performance of the nurses. Accordingly, improvement efforts are recommended for the existing obstacles.
\end{abstract}

Keywords: service performance, Gross Death Rate (GDR), theory of constraint

\begin{abstract}
ABSTRAK
Trend angka Gross Death Rate (GDR) RSU Haji Surabaya cenderung meningkat dari tahun 2012 hingga tahun 2015 namun pada tahun 2016 menurun. Penelitian ini bertujuan untuk menganalisis kendala yang ada dalam kinerja pelayanan di Instalasi Rawat Inap RSU Haji Surabaya dengan pendekatan theory of constraint sehingga dapat meminimalkan kendala dan trend angka GDR tidak meningkat dari tahun ke tahun. Penelitian ini merupakan penelitian observasional deskriptif dengan rancang bangun cross sectional. Kuesioner diberikan secara langsung kepada responden yaitu perawat sebagai cara pengumpulan data primer. Hasil penelitian menunjukkan bahwa yang menjadi kendala sumberdaya adalah beban kerja, kelengkapan sarana dan prasarana, kelengkapan alat medis dan non medis, dan kekurangan jumlah petugas. Sehingga dapat disimpulkan bahwa dengan adanya hambatan sumberdaya berupa beban kerja, kelengkapan sarana dan prasarana, kelengkapan alat medis dan non medis dan kekurangan jumlah petugas tidak mempengaruhi secara langsung terhadap kinerja pelayanan perawat. sehingga dapat direkomendasikan upaya perbaikan untuk kendala yang ada.
\end{abstract}

Kata kunci: kinerja pelayanan, Gross Death Rate (GDR), theory of constraint

\section{PENDAHULUAN}

Constraint atau kendala menjadi semua hal yang dapat membatasi sistem baik perusahaan maupun organisasi dalam mencapai target perusahaan atau organisasi (Goldratt, 2004). Setiap organisasi memiliki keterbatasan sumber daya dalam setiap proses kegiatan untuk mencapai tujuan (Hansen dan Mowen, 2007).
Keterbatasan organisasi inilah yang dimaksud dengan constraint atau kendala.

Theory of constraint atau dikenal dengan TOC diartikan sebagai pendekatan untuk peningkatan proses yang berfokus pada unsur-unsur yang menjadi kendala dan membatasi performa untuk meninggikan output. Theory of constraint menjelaskan bahwa kinerja organisasi pasti dibatasi minimal oleh satu constraint/kendala (Dettmer, 1998). 
Prinsip dasar TOC adalah setiap satu sistem mempunyai minimal satu buah constraint yang membatasi kinerja sistem tersebut. TOC menekankan bahwa perbaikan performa constraint akan langsung menghasilkan perbaikan performa sistem secara menyeluruh (Sadat, 2009).

Kinerja pelayanan didefinisikan sebagai seluruh hasil pada saat memberikan pelayanan selama periode tertentu, contohnya sasaran/kriteria/target yang sudah ditentukan terlebih dahulu dan sudah disepakati oleh bersama, standar dari hasil kerja. Menurut Juran (1988) dan Maxwell (1984) dalam Pohan (2007) mengatakan bahwa kinerja pelayanan rawat inap dapat diukur dan diamati melalui informasi, kompetensi teknis, hubungan antar manusia, lingkungan dan ketepatan waktu.

Rumah sakit yang mempunyai mutu pelayanan yang baik akan menjadi pilihan utama bagi masyarakat. Pelayanan yang memiliki mutu baik dari sebuah rumah sakit akan membuat persepsi dari pandangan pasien/pelanggan tentang layanan rumah sakit semakin bagus, selanjutnya akan mempengaruhi peningkatan penggunaan jasa rumah sakit sehingga kualitas pelayanan rumah sakit juga semakin baik. Menurut Satrianegara (2014), indikator pelayanan mutu pelayanan kesehatan ada beberapa, yaitu salah satunya mengukur tingkat efisiensi rumah sakit menggunakan indikator mutu pelayanan, indikator mutu pelayanan digunakan sebagai pengaturan tingkat efisiensi rumah sakit meliputi jumlah pasien jatuh dari tempat tidur, unit cost rawat jalan, jumlah pasien mengalami dekubitus, Average Length of Stay/ALOS 7-10 HARI, Bed Turn Over/BTO 5-45 kali/1 tempat tidur/tahun, Bed Occupancy Ratio/BOR 70-85\%, Turn Over Interval/TOI 1-3 hari tempat tidur yang kosong.

Rumah Sakit Umum (RSU) Haji Surabaya merupakan salah satu organisasi kesehatan yang termasuk dalam rumah sakit dengan tipe B. RSU Haji Surabaya berperan dalam meningkatkan pelayanan kesehatan sesuai dengan fungsi dan tugas pokoknya. Berdasarkan hasil pencapaian indikator kinerja pelayanan di RSU Haji Surabaya angka GDR mengalami peningkatan setiap tahun dari tahun 2012 hingga 2015 namun pada tahun 2016 menurun. Menurut Wijono dalam Satrianegara (2014) performa/kinerja rumah sakit dapat dilihat melalui performa pelayanan antara lain Average Length of Stay/ALOS, Turn Over Interval/TOI, Net Death Rate/NDR, Bed Turn Over/BTO, Bed Occupancy Ratio/BOR, Gross Death Rate/GDR rata-rata kunjungan poliklinik per hari.

Berdasarkan data sekunder yang diperoleh dan telah diolah oleh peneliti trend pencapaian GDR RSU Haji Surabaya dari tahun 2012 hingga 2015 mengalami peningkatan sedangkan pada tahun 2016 menurun. Angka BOR pada tahun 2012 hingga 2016 belum mencapai target yaitu $70 \%$ dan angka GDR yang meningkat setiap tahun menunjukkan kinerja pelayanan masih ada yang belum sesuai dan harus ditingkatkan. Penelitian ini akan menggunakan pendekatan TOC yang merupakan suatu teori manajemen yang dapat membantu suatu organisasi atau perusahaan untuk mengidentifikasi hambatan-hambatan yang mempengaruhi proses produksi, kemudian dengan memaksimalkan sumber daya yang dimiliki untuk meningkatkan kinerja dan keutungan serta dapat memaksimalkan throughput.

Penelitian ini bertujuan untuk menganalisis hambatan sumber daya yang ada dalam kinerja pelayanan berdasarkan theory of constraint serta pengaruh adanya hambatan pada kinerja pelayanan perawat di instalasi rawat inap RSU Haji Surabaya. Diharapkan dengan adanya penelitian ini dapat menemukan hambatan yang ada dalam kinerja pelayanan serta dapat menggambarkan tingkat kinerja pelayanan perawat, meskipun pada suatu sistem dibatasi minimal oleh satu 
kendala/hambatan. Sehingga dapat direkomendasikan suatu upaya perbaikan untuk meminimalisir kendala tersebut.

\section{METODE PENELITIAN}

Penelitian ini merupakan penelitian observasional deskriptif yaitu hanya karena mengumpulkan fakta dari gejala yang ada dengan mengamati dan mencatat tanpa memberika perlakuan apapun kepada subyek dan deskriptif karena peneliti ingin menjelaskan hasil dari kuisioner dari hasil penelitian. Rancang bangun penelitian ini cross sectional karena dilakukan di satu waktu tertentu. Populasi penelitian ini adalah 135 perawat di instalasi rawat inap RSU Haji Surabaya. Penentuan sampel ditentukan dengan teknik simple random sampling menggunakan asumsi bahwa populasi dalam penelitian ini dianggap homogen, mudah dan estimator populasi tidak bias (Budijanto, 2015). Besar sampel penelitian ini sebanyak 56 perawat.

Pengumpulan data dilakukan dengan menggunakan kuisioner penelitian mengenai kendala dalam kinerja pelayanan instalasi rawat inap RSU Haji Surabaya berdasarkan theory of constraint. Lima langkah berurutan TOC yang dikembangkan Goldrat yang bertujuan untuk memperbaiki suatu sistem, yaitu; mengidentifikasi kendala, memanfaatkan sistem yang ada, subordinasi sumber lainnya, memaksimalkan sistem, jika ditemukan kendala baru, maka kembali ke langkah pertama. Pada penelitian ini hanya membahas tentang resource constraint yang berhubungan dengan kinerja pelayanan. Kategori constraint atau bukan constraint dihitung dengan menggunakan nilai median komposit. subvariabel dengan rentang nilai komposit 56-140 dikategorikan sebagai constraint. Sementara itu, variabel dengan rentang nilai komposit 140,1-224 dikategorikan sebagai bukan constraint.

Variabel kinerja pelayanan dalam penelitian ini diukur menggunakan skala likert yaitu nilai 4 untuk jawaban sangat tinggi, nilai 3 untuk jawaban cukup tinggi, nilai 2 untuk jawaban rendah dan nilai 1 untuk jawaban sangat rendah. Kemudian dikategorikan menurut hasil yaitu rendah dengan nilai $1-2$, sedang dengan nilai 2,013, dan kategori tinggi dengan nilai 3,01-4.

Untuk mengetahui hasil pengaruh dari resource constraint terhadap kinerja pelayanan maka dilakukan uji regresi logistik menggunakan SPSS. Penelitian ini telah memperoleh keterangan lolos kaji etik dari Komisi Etik FKM No : 299KEPK.

\section{HASIL}

TOC terdapat konsep penting yaitu bahwa semua organisasi minimal mempunyai satu kendala di dalamnya. Kendala adalah suatu aspek yang membatasi perusahaan/organisasi dalam mencapai keberhasilan. Kendala sumber daya (resource constraint) menurut Kaplan dan Atkinson (1998) merupakan kendala yang berupa kompetensi faktor input produksi, seperti jam mesin, bahan baku dan tenaga kerja. Menurut Dettmer dan Schragenheim (2000) Resource constraint merupakan kendala yang berasal dari sumber daya manusia serta mesin yang dimiliki suatu organisasi. Terdapat beberapa faktor penting dalam sumber daya yang dapat memenuhi kinerja. Mesin produksi juga dapat mempengaruhi proses dalam suatu organisasi. Resource constraint adalah segala sesuatu yang menghambat kinerja pelayanan yang berasal dari sumber daya manusia dan peralatan yang digunakan. Resource constraint terdiri dari 7 variabel yaitu beban kerja, sikap petugas, kelengkapan sarana dan prasarana, kelengkapan alat medis dan non medis, jumlah petugas, kerusakan alat medis dan non medis, dan kompetensi petugas.

Berikut ini merupakan hasil perhitungan nilai komposit untuk mengetahui mana yang constraint dan bukan constraint. 
Tabel 1. Constraint Kinerja Pelayanan Instalasi Rawat Inap RSU Haji Surabaya pada tahun 2017

\begin{tabular}{|c|c|c|c|c|c|c|}
\hline \multirow{3}{*}{ Variabel } & \multicolumn{4}{|c|}{ Penilaian Responden } & \multirow{3}{*}{$\begin{array}{c}\text { Jumlah } \\
\text { Skor } \\
\text { Komposit }\end{array}$} & \multirow{3}{*}{ Kategori Komposit } \\
\hline & \multicolumn{2}{|c|}{$\begin{array}{c}\begin{array}{c}\text { Tidak Sesuai } \\
\text { (bobot 1) }\end{array} \\
\end{array}$} & \multicolumn{2}{|c|}{$\begin{array}{c}\text { Sesuai (bobot } \\
4 \text { ) }\end{array}$} & & \\
\hline & $\mathbf{F}$ & Nilai & $\mathbf{f}$ & Nilai & & \\
\hline Beban Kerja & 28 & 28 & 28 & 112 & 140 & Constraimt \\
\hline Sikap Petugas & 6 & 6 & 50 & 200 & 206 & Bukan Constraint \\
\hline $\begin{array}{l}\text { Kelengkapan Sarana dan } \\
\text { Prasarana }\end{array}$ & 31 & 31 & 25 & 100 & 131 & Constraint \\
\hline $\begin{array}{l}\text { Kelengkapan Alat Medis } \\
\text { dan Non Medis }\end{array}$ & 28 & 28 & 28 & 112 & 140 & Constraint \\
\hline Jumlah Petugas & 41 & 41 & 15 & 60 & 101 & Constraint \\
\hline $\begin{array}{l}\text { Kerusakan Alat Medis } \\
\text { dan Non Medis }\end{array}$ & 14 & 14 & 42 & 168 & 182 & Bukan Constraint \\
\hline Kompetensi Petugas & 0 & 0 & 56 & 224 & 224 & Bukan Constraint \\
\hline
\end{tabular}

Berdasarkan Tabel 1. dapat diketahui bahwa terdapat empat variabel dengan kategori constraint. Keempat variabel tersebut yaitu beban kerja, kelengkapan sarana dan prasarana, kelengkapan alat medis dan non medis dan jumlah petugas. keempat variabel yang termasuk ke dalam kategori constraint merupakan kendala atau hambatan yang ada di dalam kinerja pelayanan perawat. terdapat tiga variabel yang masuk ke dalam kategori bukan constraint yaitu sikap petugas, kerusakan alat medis dan non medis, serta kompetensi petugas. jumlah petugas mendapatkan skor komposit terendah dan kompetensi petugas mendapatkan jumlah skor komposit tertinggi.
Tabel 2. Kategeori Variabel Kinerja Pelayanan

\begin{tabular}{|c|c|c|}
\hline Penilaian & $\begin{array}{l}\text { Jumlah } \\
\text { (Orang) }\end{array}$ & $\begin{array}{l}\text { Persentase } \\
(\%)\end{array}$ \\
\hline Rendah & 0 & 0,00 \\
\hline Sedang & 46 & 82,14 \\
\hline Tinggi & 10 & 17,86 \\
\hline Total & 56 & 100,00 \\
\hline
\end{tabular}

Berdasarkan Tabel 2. dapat diketahui bahwa kinerja pelayanan yang dilakukan oleh perawat terbanyak termasuk ke dalam kategori sedang, namun ada juga perawat yang masuk ke dalam kategori tinggi, dan tidak ada perawat yang kinerja pelayanan masuk ke dalam kategori rendah.

Tabel 3. Signifikasi Pengaruh Resource Constraint terhadap Kinerja Pelayanan

\begin{tabular}{lrrl}
\hline Variabel & $\boldsymbol{p}$ value & Exp $(\boldsymbol{\beta})$ & Ket. \\
\hline Beban Kerja & 0,525 & - & Tidak Signifikan \\
\hline Sikap Petugas & 0,999 & - & Tidak Signifikan \\
\hline Kelengkapan Sarana dan Prasarana & 0,635 & - & Tidak Signifikan \\
\hline Kelengkapan Alat Medis dan Non Medis & 0,174 & - & Tidak Signifikan \\
\hline Jumlah Petugas & 0,908 & - & Tidak Signifikan \\
\hline Kerusakan Alat Medis dan Non Medis & 0,173 & - & Tidak Signifikan \\
\hline Kompetensi Petugas & - & - & Tidak Signifikan \\
\hline
\end{tabular}


Berdasarkan Tabel 3. dapat diketahui bahwa dari uji regresi logistik berganda pada resource constraint tidak ada variabel yang signifikan mempengaruhi kinerja pelayanan di Instalasi Rawat Inap Rumah Sakit Umum Haji Surabaya. Variabel dikatakan mempengaruhi jika $p$ value $<0,05$. Pada hasil penelitian yang sudah dilakukan uji regresi logistik berganda tidak ada $p$ value $<0,05$ sehingga dapat disimpulkan bahwa tidak ada variabel yang signifikan mempengaruhi kinerja pelayanan di Instalasi Rawat Inap Rumah Sakit Umum Haji Surabaya.

Hambatan dalam kinerja pelayanan tidak mempengaruhi kinerja pelayanan perawat. Hal ini dapat dilihat pada Tabel 3. bahwa dengan adanya hambatan/ kendala tidak signifikan mempengaruhi kinerja pelayanan perawat untuk mencapai ke tingkat kinerja yang tinggi.

\section{PEMBAHASAN}

Constraint dalam kinerja pelayanan di instalasi rawat inap RSU Haji Surabaya hanya akan menghambat ke pencapaian kinerja yang lebih tinggi. Namun setelah dilakukan uji regresi logistik dapat dilihat bahwa dengan adanya constraint dalam kinerja pelayanan tidak mempengaruhi signifikan secara langsung. Constraint atau kendala sebagai segala hal yang membatasi sistem, baik organisasi ataupun perusahaan (Goldratt,2004). Constraint juga dapat didefinisikan sebagai segala sesuatu yang menghambat suatu sistem untuk mencapai kinerja yang lebih tinggi. Berdasarkan hasil penelitian pada Tabel.2 kinerja pelayanan yang dilakukan oleh perawat terbanyak masuk ke dalam kategori sedang. TOC memiliki dasar yaitu bahwa setiap organisasi minimal mempunyai satu kendala yang dapat menghambat pencapaian kinerja yang tinggi. Kendala-kendala tersebut seharusnya diidentifikasi dan diatur untuk memperbaiki kinerja, biasanya jumlah kendala terbatas dan bukan berarti kendala kapasitas. Jika suatu kendala telah dipecahkan, maka kendala berikutnya dapat diidentifikasi dan diperbaiki. Realisasi di lapangan bahwa dengan adanya hambatan dalam kinerja pelayanan, tidak mempengaruhi secara langsung ke dalam kinerja pelayanan perawat. Tingkat kinerja pelayanan perawat, meskipun adanya hambatan tidak ada yang masuk dalam kategori rendah, hanya saja masih beberapa perawat yang sudah bisa mencapai tingkat kinerja pelayanan tinggi. Tetapi sebagian besar perawat sudah masuk ke dalam kategori sedang dalam kinerja pelayanan.

Pihak manajemen harus tetap memperhatikan hambatan yang ada dalam kinerja pelayanan perawat. pihak manajemen dapat mengidentifikasi dan mengatur kendala/hambatan yang ada sehingga dapat meningkatkan dan memperbaiki kinerja pelayanan perawat serta dapat menemukan jika ada hambatan/kendala yang baru dalam kinerja pelayanan di instalasi rawat inap Rumah Sakit Umum Haji Surabaya.

Tersine (1994) mendefinisikan TOC sebagai suatu filosofi pada identifikasi atas kendala untuk pncapaian tujuan perusahaan. Dengan demikian TOC memusatkan perhatian pada kendala atau hambatan yang dapat memperlambat kiernja suatu sistem.

Langkah pertama dalam tahapan theory of constraint adalah penentuan kendala. Penentuan kendala diperoleh dari menghitung nilai constraint per variabel. Dalam penelitian ini hanya membahas tentang resource constraint yang berhubungan dengan kinerja pelayanan. Hasil perhitungan nilai constraint ditunjukkan pada Tabel 1. Setelah mengidentifikasi kendala pada langkah pertama tahapan TOC kemudian memprioritaskan hambatan/kendala mana yang akan terlebih dahulu untuk diperbaiki. Cara untuk memprioritaskan hambatan/kendala mana yang akan terlebih 
dahulu untuk diperbaiki adalah memprioritaskan menurut pengaruh terhadap tujuan, meskipun mungkin ada beberapa kendala dalam suatu periode waktu, namun biasanya hanya sedikit kendala yang sesungguhnya dalam suatu sistem.

Uji signifikan pengaruh yang telah dilakukan menggunakan SPSS dengan Uji regresi logistik berganda, maka untuk prioritas masalah dapat dilihat dari $p$ value yang paling mendekati angka 0,05 . Menggunakan angka 0,05 karena suatu variabel akan signifikan berpengaruh jika $p$ value menunjukkan angka kurang dari 0,05. Maka dari hasil penelitian Tabel 3 . variabel yang mendekati angka 0,05 adalah kelengkapan alat medis dan non medis dengan $p$ value sebesar 0,174 , beban kerja dengan $p$ value 0,525 , kelengkapan sarana dan prasarana dengan $p$ value 0,635 , dan jumlah petugas dengan $p$ value 0,908. Jadi untuk memperbaiki hambatan/kendala yang ada di Instalasi Rawat Inap Rumah Sakit Umum Haji Surabaya prioritas hambatan/kendala yang akan diperbaiki terlebih dahulu adalah kelengkapan alat medis dan non medis kemudian beban kerja petugas. Setelah hambatan/kendala di prioritaskan maka dapat berlanjut ke langkah kedus dalam theory of constraint yaitu menemukan solusi dari hambatan/kendala yang telah ditemukan.

Langkah kedua dalam tahapan Theory Of Constraint adalah menemukan solusi dari hambatan/kendala yang telah ditemukan. Dalam mengatasi kendala yang ada ditentukan dengan memaksimalkan sumber daya yang dimiliki. Yang termasuk ke dalam kategori constraint ialah variabel kelengkapan alat medis dan non medis, beban kerja, kelengkapan sarana dan prasarana, serta jumlah petugas. Penjelasan tentang empat variabel yang termasuk constraint adalah sebagai berikut.

\section{Kelengkapan Alat Medis dan Non Medis}

Langkah pertama yaitu mengidentifikasi kendala pada variabel kelengkapan alat medis dan non medis.
Kelengkapan alat kesehatan krusial menurut Depkes (2008) yaitu faktor yang memegang peranan penting dalam menyelenggarakan pelayanan kesehatan kepada masyarakat adalah peralatan kesehatan. Perlunya dukungan dari peralatan kesehatan yang selalu dalam keadaan lengkap jenis, dapat difungsikan dengan baik serta siap pakai dapat menghasilkan pelayanan kesehatan yang berkesinambungan. Jika alat medis dan non medis lengkap maka kinerja pelayanan yang dilakukan petugas pun juga baik dan seimbang. Sebaliknya jika alat medis dan non medis tidak lengkap maka kinerja pelayanan yang dilakukan petugas tidak akan bisa maksimal. Berdarkan hasil penelitian pada Tabel 1. Kelengkapan alat medis dan non medis termasuk ke dalam kategori constraint.

Kelengkapan alat medis dan non medis menjadi salah satu hambatan dalam kinerja pelayanan yang ada di instalasi rawat inap Rumah Sakit Umum Haji Surabaya namun tidak signifikan berpengaruh terhadap kinerja pelayanan petugas. Pada ayat 1 pasal 16 UU. No. 44 Tahun 2009 tentang Rumah Sakit mengatakan bahwa peralatan medik dan non medik harus memenuhi standar pelayanan, persyaratan mutu baik dari segi kecukupan jumlah

Lengkap tidaknya alat medis dan non medis termasuk dalam kelengkapan sarana di rumah sakit, menurut Depkes (2008) pelayanan kesehatan perlu didukung dengan peralatan yang selalu dalam keadaan siap pakai serta dapat difungsikan dengan baik agar dapat berkesinambungan. Alat medis di instalasi rawat inap Rumah Sakit Umum Haji Surabaya masih ada yang belum dikalibrasi, dikarenakan pada saat akan dilakukan jadwal kalibrasi alat tersebut masih dipakai oleh pasien yang sedang rawat inap sehingga harus dilakukan penundaan jadwal kalibrasi.

Kalibrasi merupakan serangkaian kegiatan yang bertujuan menentukan kebenaran konvensional nilai penunjukan 
alat ukur dengan cara membandingkan terhadap standar ukur yang mampu tertelusur pada standar nasional maupun internasional. Peralatan medis harus dikalibrasi dan diuji oleh Balai Pengujian Fasilitas Kesehatan institusi pengujian fasilitas kesehatan yang berwenang dan/atau institusi pengujian fasilitas kesehatan secara berkala (UU No. 44 Tahun 2009 Pasal 16 ayat 2). Kelengkapan alat medis dan non medis tidak signifikan mempengaruhi secara langsung terhadap kinerja pelayanan petugas terhadap pasien, namun tetap harus diperhatikan agar tidak mempengaruhi sistem yang lainnya secara langsung yaitu mutu pelayanan.

Langkah kedua adalah menemukan solusi dari hambatan/kendala yang telah ditemukan. Rekomendasi upaya perbaikan yang dapat dilakukan adalah dengan mengadakan pengadaan barang/alat medis dan non medis yang dibutuhkan, kemudian melakukan perencanaan dan membuat daftar alat yang akan dikalibrasi sehingga pada saat jadwal yang telah ditentukan alat yang akan dikalibrasi tidak sedang terpakai oleh pasien rawat inap. Kalibrasi peralatan medis juga harus dilakukan secara berkala agar dapat berfungsi dengan baik. meski demikian, alat yang sudah dikalibrasi saja tidaklah cukup. Hal ini juga perlu didukung dengan pengoperasian oleh tenaga ahli, sehingga diperluka sumber daya manusia yang mampu dan menguasai cara operasi alat tersebut.

\section{Beban Kerja}

Langkah pertama yaitu mengidentifikasi kendala pada variabel beban kerja. Beban kerja adalah sejumlah aktivitas yang wajib diselesaikan dalam periode waktu tertentu oleh pemegang jabatan atau suatu unit organisasi (Menpan, 1997). Kinerja merupakan pencapaian yang dapat di capai oleh karyawan dalam melaksanakan pekerjaan pada suatu organisasi (Wibowo, 2011). Berdasarkan hasil penelitian pada Tabel 1. Diketahui bahwa beban kerja termasuk ke dalam kategori constraint.
Kinerja perawat salah satunya dapat dipengaruhi oleh beban kerja. Beban kerja perawat menurut Marquis dan Houston (2000) diartikan sebagai semua aktivitas/kegiatan yang dilakukan perawat selama bekerja/bertugas pada unit pelayanan keperawatan. Beban kerja dapat didefinisikan sebagai patient days yang melihat pada jumlah prosedur pemeriksaan kunjungan pada pasien. Terdapat dua macam beban kerja, yaitu beban kerja kualitatif dan beban kerja kuantitatif. Beban kerja kualitatif adalah tanggung jawab yang tinggi dalam memberikan asuhan kepada pasien, sedangkan beban kerja kuantitatif adalah besarnya tugas/pekerjaan yang harus dilaksanakan untuk memenuhi keperluan pasein.

Ilyas (2002) mengatakan bahwa kelelahan dan keletihan dapat disebabkan oleh beban kerja perawat yang tinggi. Kelelahan dan keletihan perawat dapat terjadi apabila perawat melakukan pekerjaan lebih dari $80 \%$ dari standar waktu kerja mereka. Dapat dikatakan bahwa waktu produktif bekerja perawat yaitu kurang lebih $80 \%$, jika perawat bekerja lebih maka beban kerja perawat tidak sesuai dan dikatakan tinggi, sehingga perlu adanya pertimbangan untuk menambah jumlah perawat di ruang perawatan yang bersangkutan dan memerlukan tambahan tenaga perawat.

Menurut Mudayana (2012) untuk beban kerja karyawan butuh untuk dikaji dan diperhatikan agar tidak terjadi kelebihan yang dapat mengakibatkan stress yang mempengaruhi pada performance karyawan. Beban kerja petugas di instalasi rawat inap Rumah Sakit Umum Haji Surabaya tidak berpengaruh secara langsung terhadap kinerja perawat namun dapat menimbulkan stress yang berakibat pada kinerjanya. Glasser, dkk (1999) beban kerja yang tinggi dapat menimbulkan stress sehingga mempengaruhi kinerja. Besar kecilnya beban kerja tidak akan mempengaruhi kinerja karyawan jika tidak merasakan stress. 
Beban kerja menjadi kendala dalam kinerja pelayanan meskipun tidak berpengaruh secara langsung namun dapat berakibat pada sistem yang lainnya secara tidak langsung, seperti stress kerja dan kelelahan kerja yang dapat berdampak kepada performance perawat dalam melakukan pelayanan. Langkah kedua yaitu menemukan solusi dari hambatan/kendala yang telah ditemukan. Rekomendasi upaya perbaikan yang dapat diberikan adalah dengan melakukan evaluasi, monitoring serta perbaikan terhadap pemberian beban kerja perawat sesuai dengan aturan, kemampuan dan kapasitas sumber daya manusia. Pemberian beban kerja yang sesuai untuk petugas adalah agar beban kerja berada di batas yang sesuai dan wajar dengan tugas yang telah diberikan di instalasi rawat inap Rumah Sakit Umum Haji Surabaya. Beban kerja yang normal dapat mempertahankan kinerja perawat karena perawat akan merasa nyaman dan tidak mengalami stress dan kelelahan dalam bekerja sehingga kinerja perawat akan meningkat dan menjadi lebih baik.

\section{Kelengkapan Sarana dan Prasarana}

Langkah pertama yatiu mengidentifikasi kendala pada variabel kelengkapan sarana dan prasarana. Sarana dan prasarana secara umum adalah alat penunjang keberhasilan suatu proses yang dilakukan di dalam pelayanan publik, karena apabila keduanya tidak tersedia maka semua kegiatan yang sudah dilakukan tidak bisa mencapai hasil yang telah diharapkan sesuai yang sudah direncanakan.

Menurut Rundungan, dkk (2015) peralatan untuk bekerja harus dipelihara sesuai dengan prosedur, standar, metode siap pakai, sebab jika tidak maka adanya gangguan pada sarana kerja bisa berakibat fatal. Prasarana yang menjadi fasilitas penunjang dari sarana diharapkan sesuai dengan aturan/standar yang telah ditetapkan dan lengkap sehingga dapat meningkatkan kualitas mutu layanan.
Berdasarkan hasil penelitian pada Tabel 1. Kelengkapan sarana dan prasarana termasuk ke dalam kategori constraint.

Menurut Rundungan, dkk (2015) fasilitas yang ada seharusnya dengan jenis dan jumlah yang memadai dan selalu dalam keadaan siap pakai dan ditunjang ddengan fasilitas yang lengkap untuk melakukan tindakan. Kelengkapan sarana dan prasarana di instalasi rawat inap Rumah Sakit Umum Haji Surabaya masih perlu adanya perbaikan seperti pada lift yang menuju ke instalasi rawat inap shofa dan marwah. Kelengkapan sarana dan prasarana tidak mempengaruhi signifikan secara langsung terhadap kinerja pelayanan perawat terhadap pasien, namun tetap harus diperhatikan agar tidak mempengaruhi sistem yang lainnya secara tidak langsung yaitu mutu pelayanan. Selain dari kelengkapan dan penyediaan sarana dan prasarana, pemeliharaan dari sarana dan prasarana perlu diperhatikan. Pemeliharaan sarana dan prasarana dapat ditinjau salah satunya adalah kecepatan waktu. Kecepatan waktu adalah waktu yang diperlukan dimulai dari laporan suatu alat rusak diterima hingga ditanggapinya laporan oleh petugas pemeriksaan.

Langkah kedua yaitu menemukan solusi dari hambatan/kendala yang telah ditemukan. Rekomendasi upaya perbaikan yang dapat dilakukan adalah dengan memaksimalkan sarana dan prasarana yang ada, lalu mengadakan pengadaan barang/alat yang dibutuhkan, melakukan kerja sama operasional dengan pihak ketiga. Contohnya, seperti suatu alat yang telah dipinjami oleh distributor atau pabriknya kemudian dari pihak rumah sakit hanya membeli reagen atau bisa juga alat dari pihak ketiga sharing tariff, pembagian tariff tergantung kesepakatan dari pihak terkait bisa 70\%-30\%, 60\%$40 \%$ atau sesuai dengan kesepakatan per tindakan. Dari segi sumber daya manusia dapat ikut serta dalam pelatihan, pendidikan lanjutan, kursus singkat keahlian yang dapat meningkatkan kualitas 
dari sumber daya manusia sehingga kinerja pelayanan perawat dapat meningkat.

\section{Jumlah Petugas}

Langkah pertama yaitu mengidentifikasi kendala dari variabel jumlah petugas. Rumah sakit yaitu perusahaan pelayanan jasa, dimana hasil yang dihasilkan sifatnya tidak berwujud dan berasal dari pemberi pelayanan yang dalam hal ini adalah SDM atau petugas. Sumber daya manusia merupakan aspek penting baik pada produksi maupun penyampaian jasa. Sumber daya manusia menjadi bagian penting dimana perusahaan jasa menciptakan nila tambah dan memperoleh keunggulan kompetensinya. Jumlah petugas (perawat) yang belum dapat dipenuhi oleh pihak Rumah Sakit Umum Haji Surabata sesuai dengan perkembangan pelayanan dan pertambahan jumlah pasien menjadi kendala dalam kerja pelayanan di instalasi rawat inap Rumah Sakit Umum Haji Surabaya. Berdasarkan hasil penelitian pada Tabel 1. diketahui bahwa kurangnya jumlah petugas termasuk ke dalam kategori constraint.

Kurangnya jumlah petugas tidak signifikan secara langsung mempengaruhi kinerja pelayanan. Dalam melakukan upaya rumah sakit dalam memberikan pelayanan medis yang memuaskan terdapat suatu hambatan yaitu keterbatasan fasilitas penunjang terutama teknologi kedokteran yang merupakan poin penting dalam penanganan tindak medis dan keterbatasan sumber daya. Sementara untuk menghasilkan fasilitas penunjang dan sumber daya membutuhkan biaya yang cukup tinggi sehingga untuk beberapa unsur penting dari sumber daya manusia dilalaikan. Pentingnya unsur manajemen kinerja, masih banyak manajemen rumah sakit yang kurang memahami. Pada saat sumber daya manusia dirasa sebagai salah satu aset organisasi atau perusahaan, maka proses peningkatan mutu kinerja dan biaya yang dikeluarkan akan menjadi aset jangka panjang yang dimiliki.
Global Health Workface Alliance (2011) menyatakan terlengkapinya jumlah tenaga kerja juga sangat penting karena tenaga kesehatan adalah kunci utama dalam kesuksesan pencapaian tujuan pembangunan kesehatan Jumlah petugas medis (perawat) yang belum terpenuhi di instalasi rawat inap Rumah Sakit Umum Haji Surabaya tidak signifikan secara langsung mempengaruhi kinerja pelayanan petugas, namun dapat mempengaruhi sistem yang lain seperti mutu pelayanan. Contohnya kecepatan pelayanan petugas dalam menangani pasien, karena adanya kekurangan jumlah petugas sehingga pasien harus bergantian dan menunggu giliran untuk mendapatkan pelayanan. Pasien yang tidak sabar menunggu akan mengeluh sehingga tingkat kepuasan pasien menurun dan mempengaruhi mutu pelayanan rumah sakit.

Langkah kedua yaitu menemukan solusi dari hambatan/kendala yang telah ditemukan. Kendala yang ditemukan adalah kurangnya jumlah perawat di instalasi rawat inap Rumah Sakit Umum Haji Surabaya karena adanya perkembangan pelayanan dan pertambahan jumlah pasien. Rekomendasi upaya perbaikan yang dapat dilakukan adalah pihak manajemen rumah sakit membuat rencana kebutuhan sumber daya manusia secara sesuai dan tepat. Setelah itu mengadakan rekruitmen pegawai baru khususnya perawat sesuai dengan rencana kebutuhan sumber daya manusia yang telah dibuat. kesesuaian jumlah rencana kebutuhan sumber daya manusia yang telah dibuat, agar bisa melakukan optimalisasi pada pelayanan yang sedang berkembang seiring dengan bertambahnya jumlah kunjungan pasien. Selain rekruitmen, upaya perbaikan yang dapat dilakukan adalah dengan rotasi/mutasi. Rotasi yaitu perputaran satu karyawan dari unit satu ke unit yang lain, sedangkan mutasi adalah perpindahan satu karyawan dari satu instansi ke instansi yang lain. Mutasi/rotasi perawat dapat dilihat dari analisis beban kerja perawat, jadi perawat 
yang beban kerjanya rendah dapat di rotasi/mutasi ke unit dengan beban kerja yang tinggi.

Upaya yang akan dilakukan
hambatan/kendala kelengkapan alat medis dan non medis kemudian beban kerja, kelengkapan sarana dan prasana dan yang terakhir adalah upaya perbaikan untuk jumlah petugas. Upaya yang dilakukan sesuai dengan prioritas hambatan/kendala yang diminimalisir terlebih dahulu. Upaya yang telah dilakukan diharapkan dapat meminimalisir kendala/hambatan yang dapat membatasi kinerja pelayanan perawat di instalasi rawat inap Rumah Sakit Umum Haji Surabaya. Bilamana rekomendasi upaya yang telah dilakukan masih belum bisa memecahkan kendala/hambatan yang ada, maka dapat dilakukan penilaian/evaluasi kegiatan ataupun evaluasi kebiajakan yang mendukung kinerja pelayanan.

Namun jika hambatan/kendala dapat diselesaikan dengan upaya yang telah dipilih, maka tahap selanjutnya adalah kembali ke tahap awal yaitu identifikasi kembali hambatan/kendala yang membatasi kinerja pelayanan di instalasi rawat inap Rumah Sakit Umum Haji Surabaya. Identifikasi hambatan/kendala dilakukan kembali untuk mengetahui apabila ditemukan kendala baru yang menjadi penghambat dalam kinerja pelayanan. Hal ini sesuai dengan proses atau tahap implementasi Theory Of Constraint yang merupakan siklus tidak terputus. Dengan demikian rumah sakit yang menerapkan Theory of Constraint akan dapat menyelesaikan masalah atau kendala yang ditemukan kemudian menentukan upaya perbaikan dari kendala tersebut, sehingga kinerja pelayanan akan menjadi lebih baik.

\section{SIMPULAN}

Resource constraint yang
ditemukan pada kinerja pelayanan di
Instalasi Rawat Inap Rumah Sakit Umum
Haji Surabaya yaitu empat variabel. Variabel tersebut adalah beban kerja, kelengkapan sarana dan prasarana, kelengkapan alat medis dan non medis serta kekurangan jumlah petugas. keempat variabel tersebut masuk ke dalam kategori constraint karena jumlah skor kompositnya kurang dari sama dengan 140.

Kinerja pelayanan perawat di Instalasi Rawat Inap Rumah Sakit Umum Haji Surabaya tidak signifikan mempengaruhi secara langsung meskipun adanya hambatan/kendala didalamnya, tetapi hambatan/kendala yang terjadi dapat mempengaruhi sistem lain yang ada. Rekomendasi upaya perbaikan yang dapat dilakukan adalah dengan melakukan perencanaan dan membuat daftar alat yang akan dikalibrasi, melakukan kalibrasi secara berkala, melakukan evaluasi, monitoring serta perbaikan terhadap pemberian beban kerja sesuai dengan aturan, kemampuan dan kapasitas SDM, memaksimalkan sarana dan prasarana yang ada, melakukan rotasi/mutasi pegawai.

\section{DAFTAR PUSTAKA}

Astuti, W.B. 2015. Analisis Kinerja Pelayanan Instalasi Rawat Inap RSUD Kabupaten Pacitan dengan Pendekatan Theory Of Constraint. Surabaya: Universitas Airlangga.

Cox, J.F \& Schleier, J.G. 2010. Theory Of Constraint Handbook. New York: McGraw Hill.

Dettmer, H.W. 1998. Constraint Theory: A Logic-Based Approach to System Improvement [eelectronic version], [online]

Dettmer, H.W. 2000. Constraint Management. America: Quality America Inc.

Glasser, N.D. Tatum, B.C. Nebeker, M.D. Sorensen, C.R. Aiello, R.J. 1999. Wirkload and Social Support: Effect on Performance and Stres, Human Performance, 12 (2), 155176.[https://doi.org/10.1080/08959 289909539865] 
Goldratt, E.M. 2004. The Goal: A Process of Ongoing Improvement. s.l:s.n.

Hansen, D.R., Mowen, Maryanne M. 2000. Management Accounting $6^{\text {th }} \mathrm{ed}$. USA: International Thompson Publishing.

Ilyas, Y. 2002. Kinerja, teori, penilaian, dan penelitian. Jakarta: Pusat Kajian Ekonomi Kesehatan FKM Universitas Indonesia

Kaplan, R.S. \& Atkitson, A.A. 1998. Advanced Management Accounting. New Jersey: Prentice Hall Inc.

Marquis, B.L. dan Huston, C.L. 2000. Leadership roles and management function in nursing. ( $3^{\text {rd }}$ ed) Philadelphia: Lippincot- Raven Publisher.

Menpan. 1997. Definisi Beban Kerja. [online]

Mudayana, A.A. 2012. Hubungan Beban Kerja Dengan Kinerja Karyawan Di Rumah Sakit Nur Hidayah Bantul. Yogyakarta: Fakultas Kesehatan Masyarakat. Universitas Ahmad Dahlan.

Mulyono, M.Hadi. Hamzah, Asiah. Abdullah, Zulkifli. 2013. Faktor Yang Berpengaruh Terhadap Kinerja Perawat Di Rumah Sakit Tingkat III 16.06.01 Ambon. Makassar: Fakultas Kesehatan Masyarakat UNHAS.

Pohan Imbali. 2007. Jaminan Mutu Layanan Kesehatan Dasar-Dasar Pengerian dan Penerapak EGC. Jakarta.

Puspita, Vida Indira. 2017. Analisis Kinerja Pelayanan di Instalasi Rawat Inap Rumah Sakit Umum Haji Surabaya dengan Pendekatan Theory Of Constraints. Surabaya:
Fakultas Kesehatan Masyarakat Universitas Airlangga.

Rundungan, Ria O. Rattu, AJM. Mariaty, NW. 2015. Analisis Kinerja Petugas Kesehatan Gigi Terhadap Pelayanan Kesehatan Gigi Dan Mulut Di Poliklinik Gigi RSUD Datoe Binangkang Kabupatn Bolaang Mongondow. Manado: Program Pascasarjana Fakultas Kesehatan Masyarakat Universitas Sam Ratulangi.

Sadat, S. 2009. Theory Of Constraint For Publicly Funded Health System. [online]

Satrianegara, M.F. 2014. Organisasi dan Manajemen Pelayanan Kesehatan. Jakarta: Salemba Medika.

Satria, Wa. Sidin, A Indahwaty. Noor, Noer Bahry. 2013. Hubungan Beban Kerja Dengan Kinerja Perawat Dalam Mengimplementasikan Patient Safety Di Rumah Sakit Universitas Hasanuddin Tahun 2013. Makassar: Fakultas Kesehatan Masyarakat UNHAS.

Suriana. 2014. Analisis Kinerja Perawat (Studi Ruang Rawat Inap Di Rumah Sakit Umum Daerah Tanjung Uban Provinsi Kepulauan Riau). Riau: Program Ilmu Administrasi Negara Fakultas Ilmu Sosial dan Politik Universitas Maritim Raja Ali Haji.

Tersine, R.J. 1994. Principles of Inventory and Materials Management. New Jersey: Prentice Hall Inc.

Undang-Undang Kesehatan Nomor 44 Tahun 2009 tentang Rumah Sakit.

Wibowo. 2011. Manajemen Kinerja (Edisi). Jakarta: PT Raja Grafindo Persada. 